\title{
Synthesis and Evaluation of Ca-doped $\mathrm{Sr}_{2} \mathrm{Fe}_{1.5} \mathrm{Mo}_{0.5} \mathrm{O}_{6-\delta}$ as Symmetrical Electrodes for High Performance Solid Oxide Fuel Cells
}

\begin{abstract}
XIA Tian ${ }^{1,2}$, MENG Xie ${ }^{1}$, LUO Ting ${ }^{1}$, ZHAN Zhong-Liang ${ }^{1}$
(1. CAS Key Laboratory of Materials for Energy Conversion, Shanghai Institute of Ceramics, Chinese Academy of Sciences, Shanghai 200050, China; 2. University of Chinese Academy of Sciences, Beijing 100049, China)

Abstract: A series of Ca-substituted $\mathrm{Sr}_{2} \mathrm{Fe}_{1.5} \mathrm{Mo}_{0.5} \mathrm{O}_{6-\delta}$ oxides, $\mathrm{Sr}_{2-x} \mathrm{Ca}_{x} \mathrm{Fe}_{1.5} \mathrm{Mo}_{0.5} \mathrm{O}_{6-\delta}(\mathrm{SCFMO}, x=0,0.2,0.4$ and 0.6 ), were synthesized and evaluated as potential electrodes for symmetrical solid oxide fuel cells. X-ray diffraction examination showed that all samples maintained cubic perovskite structure in both air and wet hydrogen atmospheres. Temperature programmed reduction measurements indicated that the $\mathrm{Ca}^{2+}$ substitution promoted the catalytic activity of SCFMO toward oxygen evolution reactions. Symmetrical anode fuel cell measurements showed the lowest polarization resistance in humidified hydrogen emerged at $x=0.6$. Single cells- $\mathrm{SC}_{0.6} \mathrm{FMO}\left|\mathrm{La}_{0.9} \mathrm{Sr}_{0.1} \mathrm{Ga}_{0.8} \mathrm{Mg}_{0.2} \mathrm{O}_{3}(\mathrm{LSGM})\right| \mathrm{SC} \mathrm{C}_{0.6} \mathrm{FMO}$, fabricated via tape-casting and impregnation methods, produced peak power densities of $1.05 \mathrm{~W} \cdot \mathrm{cm}^{-2}$ at $800{ }^{\circ} \mathrm{C}$ and $0.41 \mathrm{~W} \cdot \mathrm{cm}^{-2}$ at $650{ }^{\circ} \mathrm{C}$ when operating on hydrogen fuels and air oxidants. These results demonstrate $\mathrm{SC}_{0.6} \mathrm{FMO}$ is a potential electrode material for symmetrical solid oxide fuel cells.
\end{abstract}

Key words: Symmetrical Solid Oxide Fuel Cells; perovskite; electrode materials

Solid Oxide Fuel Cells (SOFCs) have attracted considerable attention as a promising power generation technology due to their high efficiencies and low emissions ${ }^{[1-3]}$. However, high manufacturing cost and poor long-term stability prevent their widespread implementation. SOFCs were typically composed of three ceramic components: a porous anode, a porous cathode and the dense electrolyte sandwiched between two electrodes to separate fuels from air ${ }^{[4]}$. Different materials were usually adopted for anode and cathode due to their different requirements, resulting in at least two separate thermal processing steps for fabrication of single cells. Recently, some materials appeared suitable as both electrodes in the symmetrical SOFCs (SSOFCs) ${ }^{[5]}$. Compared with the traditional SOFCs, SSOFCs showed advantages of simplified production process, reduced manufacturing cost as well as improved thermo-mechanical compatibility with only one type of interface present ${ }^{[6]}$. Nonetheless, the very different operating conditions of anodes and cathodes posed harsh requirements on the symmetrical electrodes. For example, the symmetrical electrode materials should show adequate chemical stability and acceptable electronic conductivities in both the oxidizing and reducing atmospheres with high catalytic activities towards both oxygen reduction and fuel oxidation reactions ${ }^{[7-8]}$.

Until now, only a few number of oxides could fulfil almost all requirements for symmetrical electrodes. In particular, $\mathrm{LaCrO}_{3}$ based perovskite exhibited good stability and conductivities over a wide range of oxygen partial pressures. Partial substitution of $\mathrm{Ca}$ or $\mathrm{Sr}$ in the $\mathrm{A}$-site, and $\mathrm{Mn}$ or $\mathrm{Fe}$ in the $\mathrm{B}$-site yielded promising symmetrical electrodes such as $\mathrm{La}_{0.7} \mathrm{Ca}_{0.3} \mathrm{Cr}_{0.97} \mathrm{O}_{3}{ }^{[9]}$, $\mathrm{La}_{0.75} \mathrm{Sr}_{0.25} \mathrm{Cr}_{0.5} \mathrm{Mn}_{0.5} \mathrm{O}_{3}{ }^{[10]}$, and $\mathrm{La}_{0.75} \mathrm{Sr}_{0.25} \mathrm{Cr}_{0.7} \mathrm{Fe}_{0.3} \mathrm{O}_{3}{ }^{[11]}$ with good catalytic activities for both electrode reactions. Maximum power densities of $300 \mathrm{~mW} \cdot \mathrm{cm}^{-2}$ were achieved in humidified hydrogen for the symmetrical $\mathrm{La}_{0.75} \mathrm{Sr}_{0.25} \mathrm{Cr}_{0.5} \mathrm{Mn}_{0.5} \mathrm{O}_{3}$ electrode fuel cells at $900{ }^{\circ} \mathrm{C}^{[10]}$. $\mathrm{La}(\mathrm{Sr}) \mathrm{TiO}_{3}$-based oxide were usually used as anodes due to their high conductivities in hydrogen and excellent catalytic activities for hydrogen oxidation reactions. Doping $\mathrm{Fe}$ or $\mathrm{Co}$ in the B-site substantially improved their conductivities under oxidizing atmospheres. $\mathrm{La}_{4} \mathrm{Sr}_{8} \mathrm{Ti}_{6} \mathrm{Fe}_{6} \mathrm{O}_{38-\delta}{ }^{[12]}$ and $\mathrm{La}_{0.5} \mathrm{Sr}_{0.5} \mathrm{Ti}_{0.5} \mathrm{Co}_{0.5} \mathrm{O}_{3-\delta}(\mathrm{LSTC})^{[13]}$ were explored as symmetrical electrodes with maximum power densities of $110 \mathrm{~mW} \cdot \mathrm{cm}^{-2}$ obtained at $800{ }^{\circ} \mathrm{C}$ for symmetrical cells-LSTC|LSGM|LSTC ${ }^{[13]}$. Alternatively, introducing the chemically stable metal element Mo in the B-site of commonly used SOFC cathodes could also enhance their structural stability under highly reducing anode atmospheres, e.g., $\mathrm{SrFe}_{0.75} \mathrm{Mo}_{0.25} \mathrm{O}_{3-\delta}$ (SFMO) ${ }^{[14]}$. Power densities as high as $0.83 \mathrm{~W} \cdot \mathrm{cm}^{-2}$ were achieved at $900{ }^{\circ} \mathrm{C}$ for symmetrical SFMO electrode fuel cells in

Received date: 2019-02-13; Modified date: 2019-04-22

Foundation item: National Natural Science Foundation of China (51672298, 51702344, 51737011); The State of Grid (SGSDJN00FZQT1700446)

Biography: XIA Tian (1993-), male, candidate of Master degree. E-mail: xiatian@student.mail.sic.ac.cn

Corresponding author: ZHAN Zhong-Liang, professor. E-mail: zzhan@mail.sic.ac.cn 
hydrogen fuels ${ }^{[15]}$. Optimizing the cell microstructure via liquid infiltration technique ${ }^{[16]}$ or phase inversion method ${ }^{[17]}$ could further improve the cell performance.

Modification of the electrode materials by metal substitution or doping while maintaining the original crystal structure may also improve the cell performance ${ }^{[6,18]}$. It was reported that partial substitution of $\mathrm{Ca}^{2+}$ for $\mathrm{Sr}^{2+}$ changed the cationic valence and oxygen-vacancy concentration, yielding increase of electrical conductivity and reduction of cathode polarization resistance in air ${ }^{[19]}$. Here, partial substitution of $\mathrm{Sr}^{2+}$ in SFMO by $\mathrm{Ca}^{2+}$ was explored with the aim of improving their performance as the symmetrical electrodes. A series of samples $\mathrm{Sr}_{2-x} \mathrm{Ca}_{x} \mathrm{Fe}_{1.5} \mathrm{Mo}_{0.5} \mathrm{O}_{6-\delta}$ (SCFMO, $x=0,0.2,0.4$ and 0.6) were synthesized and their structural stabilities in hydrogen were examined. The chemical stability and the catalytic activities toward oxygen evolution reactions (OER) of SCFM in hydrogen were evaluated by temperature programmed reduction. Thin LSGM electrolyte fuel cells with symmetrical SCFMO electrodes were fabricated by tape casting and liquid impregnation methods. The structures and electrochemical characteristics of single cells were examined to explore their potential applications in SSOFCs.

\section{Experimental}

The $\mathrm{Sr}_{2-x} \mathrm{Ca}_{x} \mathrm{Fe}_{1.5} \mathrm{Mo}_{0.5} \mathrm{O}_{6-\delta}(x=0,0.2,0.4$ and 0.6$)$ powders were synthesized via Sol-Gel method ${ }^{[20]}$. Stoichiometric amounts of $\mathrm{Sr}\left(\mathrm{NO}_{3}\right)_{2}, \mathrm{Ca}\left(\mathrm{NO}_{3}\right)_{2}, \mathrm{Fe}\left(\mathrm{NO}_{3}\right)_{3} \cdot 9 \mathrm{H}_{2} \mathrm{O}$ and $\left(\mathrm{NH}_{4}\right)_{6} \mathrm{Mo}_{7} \mathrm{O}_{24} \cdot 4 \mathrm{H}_{2} \mathrm{O}$ were dissolved in deionized water with addition of citric acid to form the SCFMO precursor solution. The precursor solutions were evaporated at $80{ }^{\circ} \mathrm{C}$ to form gel. The gel was then dried at $250{ }^{\circ} \mathrm{C}$ for $10 \mathrm{~h}$ to obtain dry precursor followed by calcination at $1100{ }^{\circ} \mathrm{C}$ in air for $5 \mathrm{~h}$ to obtain the final SCFMO powders. Crystal structure of the as-synthesized and hydrogenreduced powders were examined by X-ray diffractometer (XRD, Rigaku Smartlab9, Japan) at room temperature. Temperature-programmed reduction (TPR, Micromeritics ChemiSorb 2720) measurements were carried out to analyze the catalytic activity of SCFMO anodes. $60 \sim 80 \mathrm{mg}$ SCFMO powders were loaded into the quartz U-tube. After being pre-treated with high-purity He flow at $450{ }^{\circ} \mathrm{C}$ for $30 \mathrm{~min}$, the samples were measured under $5 \mathrm{vol} \%$ $\mathrm{H}_{2} / \mathrm{He}\left(20 \mathrm{~mL} \cdot \mathrm{min}^{-1}\right)$ flow with a linear heating rate of $10{ }^{\circ} \mathrm{C} \cdot \mathrm{min}^{-1}$ from room temperature up to $850{ }^{\circ} \mathrm{C}$.

Symmetrical fuel cells were fabricated with thin LSGM electrolytes and SCFMO catalysts, based upon the "porous|dense|porous" LSGM tri-layer backbones. Powders of LSGM (Praxair) and rice starch used as the fugitive material for the porous layers were ball-milled in a weight ratio of 60:40 for $12 \mathrm{~h}$ with appropriate amounts of dispersant, binder, plasticizer and solvent. The tri-layer structures were produced by laminating three tape-cast ceramic green tapes with subsequent co-firing at $1400{ }^{\circ} \mathrm{C}$ to produce the final ceramic structures. The electrode catalysts SCFMO were added by liquid infiltration method. The precursor solutions were simultaneously impregnated into both porous LSGM backbones, and then calcined at $700{ }^{\circ} \mathrm{C}$ for $30 \mathrm{~min}$. The impregnationcalcination procedure was repeated until catalyst loading achieved $25 \mathrm{wt} \%$ relative to the porous LSGM backbones, with a final calcination at $850{ }^{\circ} \mathrm{C}$ for $2 \mathrm{~h}$ to obtain the symmetrical cells. The cross-sectional morphologies of single cells were examined using the scanning electron microscopy (SEM, FEI Inspect F50, USA).

For electrochemical measurement at $650-800{ }^{\circ} \mathrm{C}$, the symmetrical cells were sealed to alumina tubes using ceramic adhesive (Aremco, Ultra-Temp 552). Currentvoltage curves $(I-V)$ and electrochemical impedance spectra (EIS) were obtained by using Electrochemical Workstation (ZAHNER IM6e, Germany) with the cathode exposed to dry air $\left(100 \mathrm{~mL} \cdot \mathrm{min}^{-1}\right)$ and the anode to humidified $\left(3 \mathrm{vol} \% \mathrm{H}_{2} \mathrm{O}\right)$ hydrogen $\left(100 \mathrm{~mL} \cdot \mathrm{min}^{-1}\right)$. To determine the individual electrode polarization resistances, impedance measurements were also performed on symmetrical cells in homogeneous environments, i.e., in dry air for symmetrical cathode cells and in humidified ( $3 \mathrm{vol} \% \mathrm{H}_{2} \mathrm{O}$ ) hydrogen for symmetrical anode cells. The impedance data were recorded at open circuits over the frequency range from $0.1 \mathrm{~Hz}$ to $100 \mathrm{kHz}$ with a $20 \mathrm{mV}$ AC perturbation.

\section{Results and discussion}

Fig. 1(a) summarized the room temperature XRD patterns of as-synthesized SCFMO powders, showing cubic perovskite crystal structure for all powders as previously reported $^{[19]}$. In order to examine their structural stability as the SOFC anode, these powders were thermally treated in $97 \mathrm{vol} \% \mathrm{H}_{2}-3 \mathrm{vol} \% \mathrm{H}_{2} \mathrm{O}$ at $800{ }^{\circ} \mathrm{C}$ for $4 \mathrm{~h}$, with XRD patterns of the reduced powders summarized in Fig. 1(b). Notably, the cubic perovskite structures for all samples were well maintained with little impurities detected, indicating that SCFMO oxides could be adopted as the symmetrical electrodes in SOFCs. The magnified XRD patterns at $67.5^{\circ}$ in Fig. 1(c) showed that the peak shifted toward higher angle with $\mathrm{Ca}^{2+}$ substitution increasing, due to smaller ionic radius of $\mathrm{Ca}^{2+}$ compared with $\mathrm{Sr}^{2+}$. Fig. 1(c) also showed increased lattice parameter after reduction in hydrogen due to the reduction of $\mathrm{Fe}$ and $\mathrm{Mo}$ elements as previously reported for the SFMO-based oxides $^{[21]}$. 

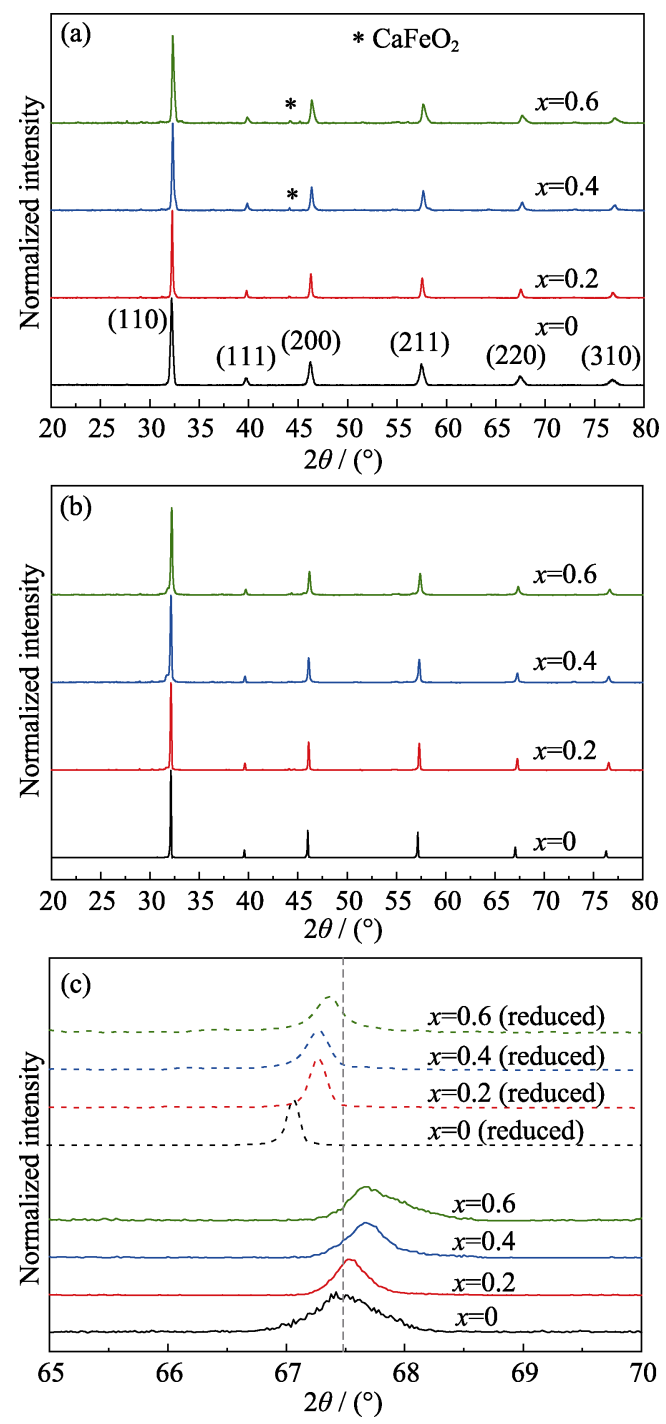

Fig. 1 XRD patterns of $\mathrm{Sr}_{2-x} \mathrm{Ca}_{x} \mathrm{Fe}_{1.5} \mathrm{Mo}_{0.5} \mathrm{O}_{6-\delta}$ powders synthetized in air (a) and reduced in humidified hydrogen (b) at $800{ }^{\circ} \mathrm{C}$ for $4 \mathrm{~h}$; (c) Magnified view of the diffraction peak at $67.5^{\circ}$

Temperature programmed reduction measurements were used to evaluate the stability and catalytic activities of the SCFMO anode materials. Fig. 2 showed the TPR profiles of all SCFMO samples, showing only one peak for the pure SFMO and two peaks for the $\mathrm{Ca}^{2+}$-substituted samples. Similar profiles were observed by Xiao, et $a l^{[22]}$ and Wang, et $a l^{[23]}$ in the TPR curves of SFMO materials, related to reduction of $\mathrm{Fe}^{3+}$ and $\mathrm{Mo}^{6+}$. Kubo, et $a l^{[24]}$ assigned the $\sim 550{ }^{\circ} \mathrm{C}$ peak to the reduction of AMoVIO4 to AMoIVO3. Thus it was reasonable to attribute the peaks at $\sim 490$ and $\sim 550{ }^{\circ} \mathrm{C}$ in TPR curves to reductions of $\mathrm{Fe}^{3+}$ and $\mathrm{Mo}^{6+}$, respectively. TPR curves shifted towards lower temperature with increasing substitution of $\mathrm{Ca}^{2+}$, indicative of enhanced OER catalytic activity ${ }^{[23]}$. Furthermore, no reduction peak reflecting the formation of metal Fe was observed in the TPR profiles, confirming the structural stability of all the

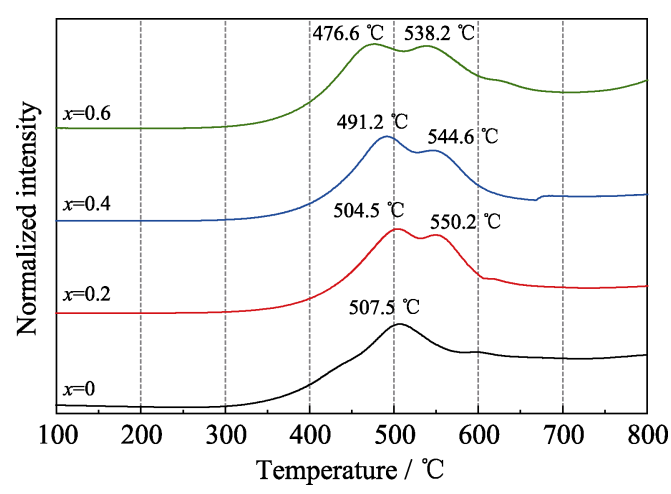

Fig. 2 Measured $\mathrm{H}_{2}$-TPR profiles for $\mathrm{Sr}_{2-x} \mathrm{Ca}_{x} \mathrm{Fe}_{1.5} \mathrm{Mo}_{0.5} \mathrm{O}_{6-\delta}$ powders with a ramp rate of $10{ }^{\circ} \mathrm{C} \cdot \mathrm{min}^{-1}$

SCFMO oxides in hydrogen as consistent with the XRD results.

Fig. 3(a) showed SEM micrograph of the thin LSGM electrolyte fuel cell with symmetrical SCFMO electrodes. The LSGM electrolyte layer was fully dense with $\sim 35 \mu \mathrm{m}$ thickness. Higher-magnification micrograph (Fig. 3(b)) of the impregnated composite electrode showed a homogeneous distribution of $70 \mathrm{~nm}$ SCFMO catalysts on the internal surfaces of the porous LSGM backbones. Fig. 3(b) also showed well-connected catalysts and sufficient porosities that were conducive to current collection and gas transport.

The catalytic activities of SCFMO nano particles toward hydrogen oxidation at the anode and oxygen reduction at the cathode were evaluated by electrochemical impedance spectroscopy (EIS). Fig. 4(a) showed Nyquist plots of impedance data measured on the symmetrical anode cells at $800{ }^{\circ} \mathrm{C}$ in the homogeneous environment of $97 \mathrm{vol} \% \mathrm{H}_{2}-3 \mathrm{vol} \% \mathrm{H}_{2} \mathrm{O}$, where the ohmic resistances were omitted for easy comparison among different samples. The anode polarization resistances $\left(R p,{ }_{A}\right)$ were 0.23 , $0.21,0.20$ and $0.18 \Omega \cdot \mathrm{cm}^{2}$ for SCFMO at $x=0,0.2,0.4$ and 0.6 , respectively. Fig. 4(b) showed the temperature dependence of the $R p,{ }_{A}$ value on the substitution amounts of $\mathrm{Ca}^{2+} . R p,{ }_{A}$ decreased with the $\mathrm{Ca}^{2+}$ substitution increasing over the whole temperature range from 650 to $800{ }^{\circ} \mathrm{C}$ with the minimized $R p,{ }_{A}$ values observed at
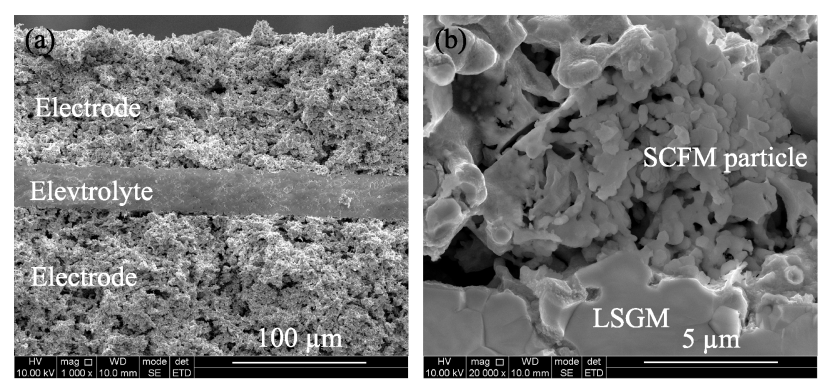

Fig. 3 Cross-sectional SEM micrographs showing impregnated fuel cells

(a) Low magnification; (b) High magnification 


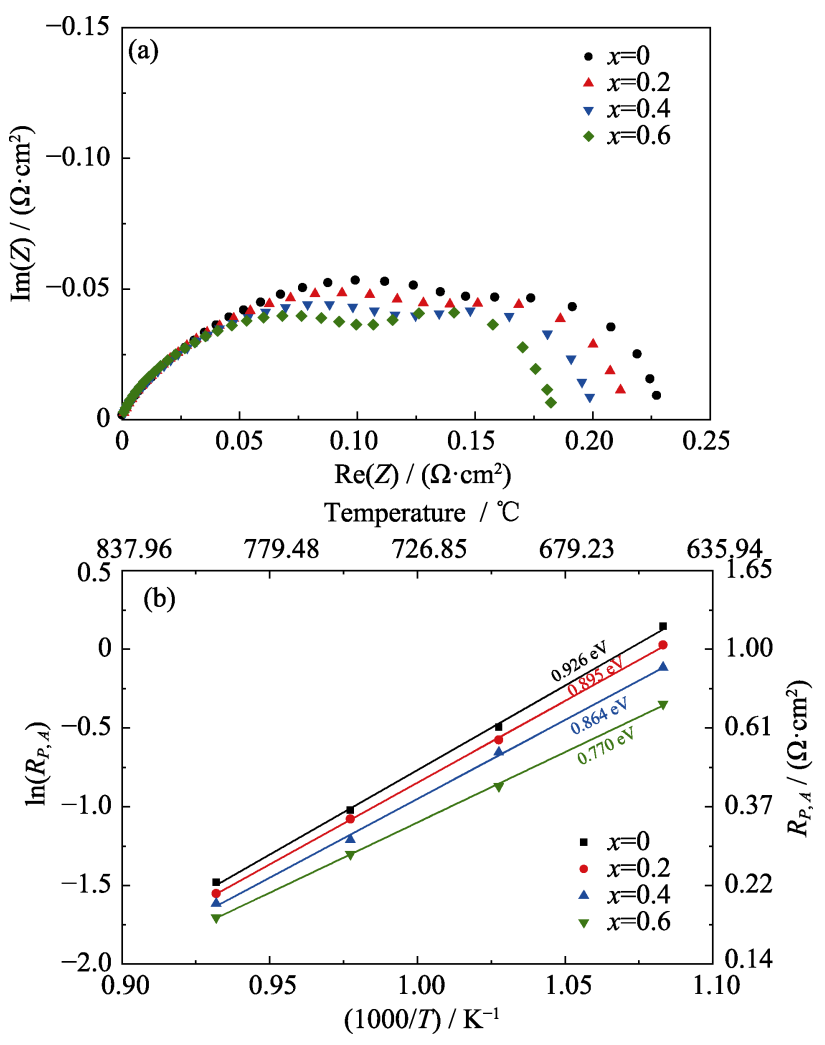

Fig. 4 (a) EIS plots of the $\mathrm{Sr}_{2-x} \mathrm{Ca}_{x} \mathrm{Fe}_{1.5} \mathrm{Mo}_{0.5} \mathrm{O}_{6-\delta}$ symmetrical cells measured in humidified hydrogen at $800{ }^{\circ} \mathrm{C}$, and (b) Arrhenius plots of the anode polarization resistances over the temperature range of $650-800{ }^{\circ} \mathrm{C}$

$x=0.6$. Moreover, the slope of Arrhenius plots in Fig. 4(b) also decreased with increasing $\mathrm{Ca}^{2+}$ substitution. The activation energy decreased from 0.93 to $0.77 \mathrm{eV}$, which were slightly smaller than $1.07 \mathrm{eV}$ in previous report ${ }^{[25]}$. These results indicated that $\mathrm{Ca}^{2+}$ substitution could effectively enhance the anode catalytic activities with reduced anode polarization resistances, especially at lower temperatures.

Fig. 5(a) showed Nyquist plots of impedance data measured on the symmetrical cathode cells at $800{ }^{\circ} \mathrm{C}$ in homogeneous air environment. The cathode polarization resistances $(R p, C)$ were $0.104,0.056,0.058$ and $0.077 \Omega \cdot \mathrm{cm}^{2}$ at $x=0,0.2,0.4$ and 0.6 , respectively. Fig. 5(b) showed the temperature dependence of the $R p,_{C}$ value on the substitution amounts of $\mathrm{Ca}^{2+}$ at $650-800{ }^{\circ} \mathrm{C}$. Minimized $R p,,_{C}$ values emerged at $x=0.2$ with all temperatures, similar to the observation in previous report ${ }^{[19]}$. However, the slope of the curve in Arrhenius plots was close to each other for all SCFMO cathodes, indicating that $\mathrm{Ca}^{2+}$ substitution might not alter the cathode reaction mechanism. And the increase in conductivity may be the reason for improvement of cathode performance ${ }^{[19]}$. However, compared with the resistance of cathode, higher anode impedance of the SCFMO electrode showed more significant impact on the cell performance, especially at

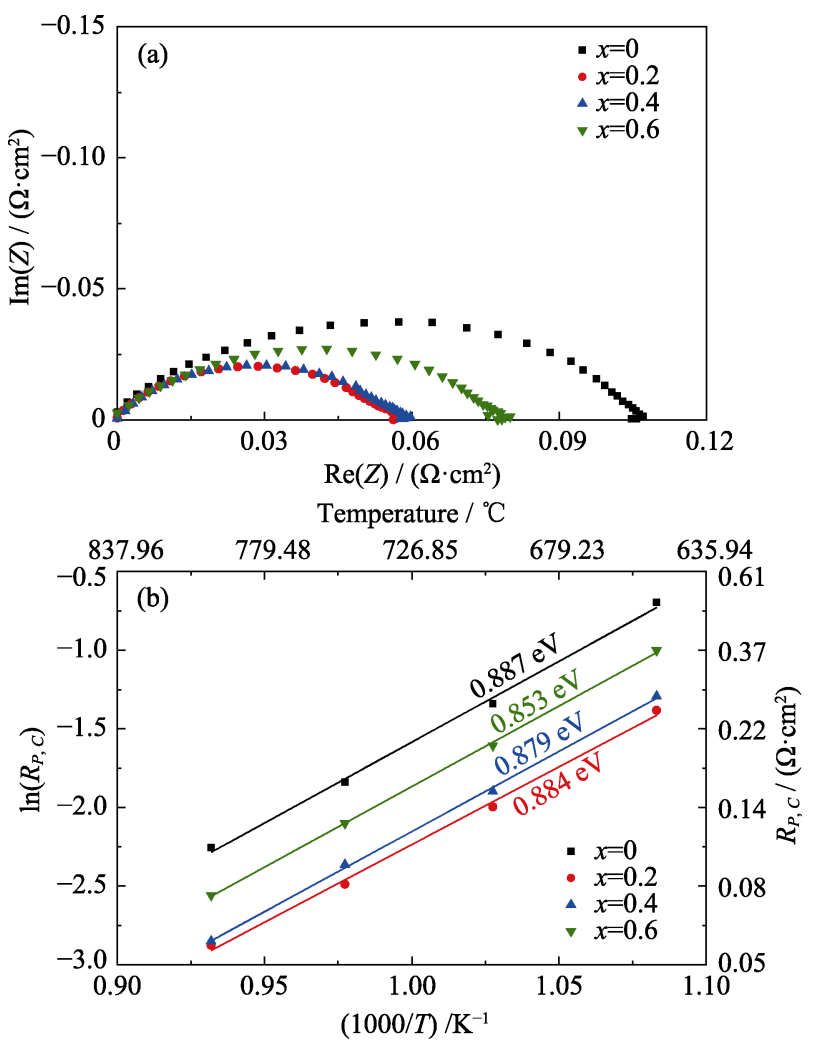

Fig. 5 (a) EIS plots of the $\mathrm{Sr}_{2-x} \mathrm{Ca}_{x} \mathrm{Fe}_{1.5} \mathrm{Mo}_{0.5} \mathrm{O}_{6-\delta}$ symmetrical cells measured in air at $800{ }^{\circ} \mathrm{C}$, and (b) Arrhenius plots of the cathode polarization resistances over the temperature range of $650-800{ }^{\circ} \mathrm{C}$

lower temperatures. Although the cathode impedances of the electrode were low at $x=0.2$, the minimum value of the total polarization impedance of the cells was achieved at $x=0.6$.

Fuel cell performances were measured in humidified hydrogen fuels and dry air oxidants both at a flow rate of $100 \mathrm{~mL} \cdot \mathrm{min}^{-1}$. Fig. 6(a) showed the polarization curves of the cell voltages $(V)$ and power densities $(P)$ as a function of current densities $(J)$ measured over $650-800{ }^{\circ} \mathrm{C}$ for the symmetrical SCFMO electrodes with $x=0.6$. The open circuit voltage (OCV) values increased from $1.103 \mathrm{~V}$ at $800{ }^{\circ} \mathrm{C}$ to $1.127 \mathrm{~V}$ at $650{ }^{\circ} \mathrm{C}$, which were close to the theoretical values $(1.12-1.15 \mathrm{~V})$ calculated from Nernst equation over the very temperature range. The maximum power densities were $1.05,0.88,0.66$ and $0.41 \mathrm{~W} \cdot \mathrm{cm}^{-2}$ at $800,750,700$ and $650{ }^{\circ} \mathrm{C}$, respectively. Fig. 6(b) showed Nyquist plots of impedance data obtained at open circuit, and the combined anode and cathode interfacial polarization resistances were $0.155,0.179,0.230$ and $0.359 \Omega \cdot \mathrm{cm}^{2}$ at $800,750,700$ and $650{ }^{\circ} \mathrm{C}$, respectively. The polarization impedance and the ohmic impedance increased gradually with the operating temperature decreasing in Nyquist plots, indicating decrease in the catalytic activity of the electrodes and the electrical conductivity of the electrolyte. 

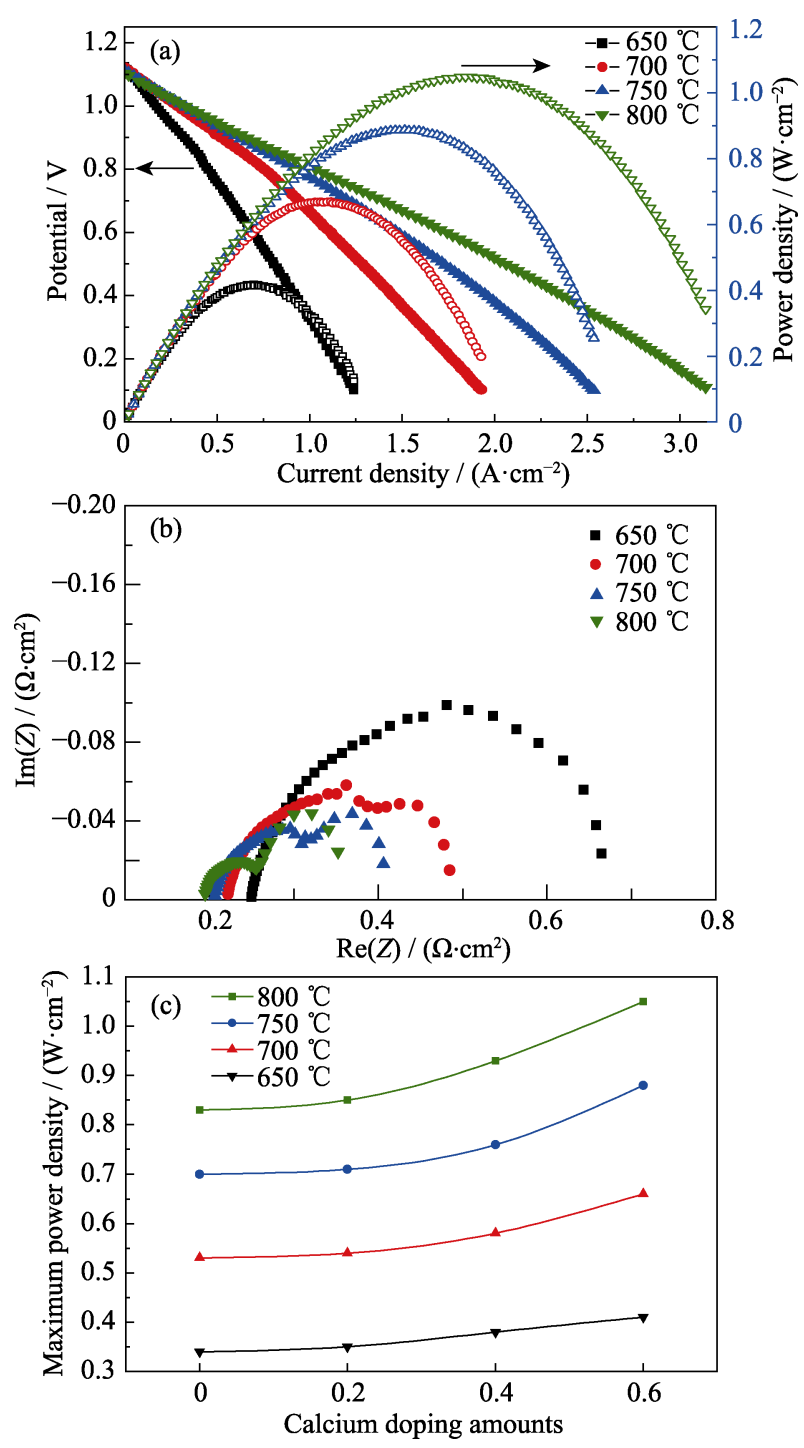

Fig. 6 (a) Voltage and power density versus current density for a symmetrical fuel cell with $\mathrm{Sr}_{2-x} \mathrm{Ca}_{x} \mathrm{Fe}_{1.5} \mathrm{Mo}_{0.5} \mathrm{O}_{6-\delta}(x=0.6)$ electrode measured in humidified hydrogen fuel and dry air over the temperature range of $650-800{ }^{\circ} \mathrm{C}$; (b) Nyquist plots of impedance data measured at open circuits; (c) Maximum power densities of the symmetrical SCFMO electrode cells at different $\mathrm{Ca}^{2+}$ substitutions over the temperature range of $650-800{ }^{\circ} \mathrm{C}$

Compared with our prior symmetrical SFMO electrode cells $^{[16]}$, the present fuel cell showed lower polarization resistance and higher power density, even though the electrolyte of the present fuel cell in Fig. 3(a) was almost twice thick. Decreasing the electrolyte thickness will further enhance the fuel cell performance. Fig. 6(c) summarized the maximum power densities for all symmetrical fuel cells with different $\mathrm{Ca}^{2+}$ substitutions at $650-800{ }^{\circ} \mathrm{C}$. The samples with $x=0.6$ exhibited the highest power densities at all temperatures, in agreement with the observed total polarization impedance and the H-TPR measurements. These results demonstrate that $\mathrm{Sr}_{1.4} \mathrm{Ca}_{0.6} \mathrm{Fe}_{1.5} \mathrm{Mo}_{0.5} \mathrm{O}_{6-\delta}$ is a kind of promising symmetrical fuel cell electrode material.

\section{Conclusion}

In summary, we synthesized and evaluated a series of $\mathrm{Sr}_{2-x} \mathrm{Ca}_{x} \mathrm{Fe}_{1.5} \mathrm{Mo}_{0.5} \mathrm{O}_{6-\delta}(x=0,0.2,0.4$ and 0.6$)$ oxides as potential electrode catalysts for symmetrical fuel cells. These oxides maintained cubic perovskite crystal structure under both oxidizing and reducing conditions. $\mathrm{H}_{2}$-TPR measurements indicated that substituting $\mathrm{Ca}^{2+}$ for $\mathrm{Sr}^{2+}$ reduced the onset temperature of hydrogen oxidation reactions. Impedance analysis showed that $\mathrm{Sr}_{1.4} \mathrm{Ca}_{0.6} \mathrm{Fe}_{1.5} \mathrm{Mo}_{0.5} \mathrm{O}_{6-\delta}$ exhibited the lowest anode polarization resistances among all samples with slighltly higher cathode polarization resistances than those of $\mathrm{Sr}_{1.6} \mathrm{Ca}_{0.4} \mathrm{Fe}_{1.5} \mathrm{Mo}_{0.5} \mathrm{O}_{6-\delta}$. Fuel cell measurements also showed the highest power densities for symmetrical $\mathrm{Sr}_{1.4} \mathrm{Ca}_{0.6} \mathrm{Fe}_{1.5} \mathrm{Mo}_{0.5} \mathrm{O}_{6-\delta}$ electodes, e.g., 1.05, 0.88, 0.66 and $0.41 \mathrm{~W} \cdot \mathrm{cm}^{-2}$ at $800,750,700$ and $650{ }^{\circ} \mathrm{C}$, respectively. These results indicate that $\mathrm{Ca}^{2+}$ substitution is effective in enhancing the catalytic activity of SFMO oxides toward hydrogen oxidation and oxygen reduction reactions, and $\mathrm{Sr}_{1.4} \mathrm{Ca}_{0.6} \mathrm{Fe}_{1.5} \mathrm{Mo}_{0.5} \mathrm{O}_{6-\delta}$ is a promising symmetrical electrode material.

\section{References:}

[1] ORMEROD R M. Solid oxide fuel cells. Chemical Society Reviews, 2003, 32(1): 17-28.

[2] MINH N Q. Solid oxide fuel cell technology-features and applications. Solid State Ionics, 2004, 174(1): 271-277.

[3] IRVINE J T S, CONNOR P. SOFC Facts and Figures: Past Present and Future Perspectives for SOFC Technologies. London: Springer London, 2013.

[4] STEELE B C H, HEINZEL A. Materials for fuel-cell technologies. Nature, 2001, 414: 345-352.

[5] CARLOS RUIZ-MORALES J, MARRERO-LOPEZ D, CANALES-VAZQUEZ J, et al. Symmetric and reversible solid oxide fuel cells. RSC Adv., 2011, 1(8): 1403-1414.

[6] SU C, WANG W, LIU M, et al. Progress and prospects in symmetrical solid oxide fuel cells with two identical electrodes. Advanced Energy Materials, 2015, 5(14): 1500188.

[7] DOS SANTOS-GÓMEZ L, PORRAS-VÁZQUEZ J M, LOSILLA $\mathrm{E} \mathrm{R}$, et al. Ti-doped $\mathrm{SrFeO}_{3}$ nanostructured electrodes for symmetric solid oxide fuel cells. RSC Adv., 2015, 5(130): 107889-107895.

[8] BIAN L, DUAN C, WANG L, et al. Ce-doped $\mathrm{La}_{0.7} \mathrm{Sr}_{0.3} \mathrm{Fe}_{0.9} \mathrm{Ni}_{0.1} \mathrm{O}_{3-\delta}$ as symmetrical electrodes for high performance direct hydrocarbon solid oxide fuel cells. Journal of Materials Chemistry A, 2017, 5(29): 15253-15259.

[9] LIN B, WANG S, LIU X, et al. Simple solid oxide fuel cells. Journal of Alloys and Compounds, 2010, 490(1): 214-222.

[10] BASTIDAS D M, TAO S, IRVINE J T S. A symmetrical solid oxide fuel cell demonstrating redox stable perovskite electrodes. $J$. Mater. Chem., 2006, 16(17): 1603-1605.

[11] CHEN M, PAULSON S, THANGADURAI V, et al. Sr-rich chromium ferrites as symmetrical solid oxide fuel cell electrodes. Journal of Power Sources, 2013, 236: 68-79.

[12] CANALES-VÁZQUEZ J, RUIZ-MORALES J C, MARREROLÓPEZ D, et al. Fe-substituted $(\mathrm{La}, \mathrm{Sr}) \mathrm{TiO}_{3}$ as potential electrodes 
for symmetrical fuel cells (SFCs). Journal of Power Sources, 2007, 171(2): 552-557.

[13] MARTíNEZ-CORONADO R, AGUADERO A, PÉREZ-COLL D, et al. Characterization of $\mathrm{La}_{0.5} \mathrm{Sr}_{0.5} \mathrm{Co}_{0.5} \mathrm{Ti}_{0.5} \mathrm{O}_{3-\delta}$ as symmetrical electrode material for intermediate-temperature solid-oxide fuel cells. International Journal of Hydrogen Energy, 2012, 37(23): 18310-18318.

[14] FERNANDEZ-ROPERO A J, PORRAS-VAZQUEZ J M, CABEZA A, et al. High valence transition metal doped strontium ferrites for electrode materials in symmetrical SOFCs. J. Power Sources, 2014, 249: 405-413.

[15] LIU Q, DONG X, XIAO G, et al. A novel electrode material for symmetrical SOFCs. Advanced Materials, 2010, 22(48): 5478-5482.

[16] MENG X, LIU X J, DA H, et al. Symmetrical solid oxide fuel cells with impregnated $\mathrm{SrFe}_{0.75} \mathrm{Mo}_{0.25} \mathrm{O}_{3-\delta}$ electrodes. J. Power Sources, 2014, 252: 58-63.

[17] GAO J, MENG X, LUO T, et al. Symmetrical solid oxide fuel cells fabricated by phase inversion tape casting with impregnated $\mathrm{SrFe}_{0.75} \mathrm{Mo}_{0.25} \mathrm{O}_{3-\delta}$ (SFMO) electrodes. International Journal of Hydrogen Energy, 2017, 42(29): 18499-18503.

[18] LIU F, ZHANG L, HUANG G, et al. High performance ferritebased anode $\mathrm{La}_{0.5} \mathrm{Sr}_{0.5} \mathrm{Fe}_{0.9} \mathrm{Mo}_{0.1} \mathrm{O}_{3-\delta}$ for intermediate-temperature solid oxide fuel cell. Electrochimica Acta, 2017, 255: 118-126.

[19] QIAO J, CHEN W, WANG W, et al. The Ca element effect on the enhancement performance of $\mathrm{Sr}_{2} \mathrm{Fe}_{1.5} \mathrm{Mo}_{0.5} \mathrm{O}_{6-\delta}$ perovskite as cathode for intermediate-temperature solid oxide fuel cells. J. Power Sources, 2016. 331: 400-407.

[20] MENG X, HAN D, WU $\mathrm{H}$, et al. Characterization of $\mathrm{SrFe}_{0.75} \mathrm{Mo}_{0.25} \mathrm{O}_{3-\delta}-\mathrm{La}_{0.9} \mathrm{Sr}_{0.1} \mathrm{Ga}_{0.8} \mathrm{Mg}_{0.2} \mathrm{O}_{3-\delta}$ composite cathodes prepared by infiltration. Journal of Power Sources, 2014, 246(Supplement C): 906-911.

[21] MUÑOZ-GARCÍA A B, BUGARIS D E, PAVONE M, et al. Unveiling structure-property relationships in $\mathrm{Sr}_{2} \mathrm{Fe}_{1.5} \mathrm{Mo}_{0.5} \mathrm{O}_{6-\delta}$, an electrode material for symmetric solid oxide fuel cells. Journal of the American Chemical Society, 2012, 134(15): 6826-6833.

[22] XIAO G L, CHAO J, QING L, et al. Ni modified ceramic anodes for solid oxide fuel cells. Journal of Power Sources, 2012, 201: 43-48.

[23] WANG Y, LIU T, LI M, et al. Exsolved $\mathrm{Fe}-\mathrm{Ni}$ nano-particles from $\mathrm{Sr}_{2} \mathrm{Fe}_{1.3} \mathrm{Ni}_{0.2} \mathrm{Mo}_{0.5} \mathrm{O}_{6}$ perovskite oxide as a cathode for solid oxide steam electrolysis cells. Journal of Materials Chemistry A, 2016, 4(37): 14163-14169.

[24] KUBO J, UEDA W. Catalytic behavior of $\mathrm{AMoO}_{x}(\mathrm{~A}=\mathrm{Ba}, \mathrm{Sr})$ in oxidation of 2-propanol. Materials Research Bulletin, 2009, 44(4): 906-912.

[25] HE B, ZHAO L, SONG S, et al. $\mathrm{Sr}_{2} \mathrm{Fe}_{1.5} \mathrm{Mo}_{0.5} \mathrm{O}_{6-\delta}-\mathrm{Sm}_{0.2} \mathrm{Ce}_{0.8} \mathrm{O}_{1.9}$ composite anodes for intermediate-temperature solid oxide fuel cells. Journal of The Electrochemical Society, 2012, 159(5): B619-B626.

\title{
$\mathrm{Ca}$ 掺杂 $\mathrm{Sr}_{2} \mathrm{Fe}_{1.5} \mathrm{Mo}_{0.5} \mathrm{O}_{6-\delta}$ 材料的合成与作为对称固体 氧化物燃料电池电极催化剂的性能研究
}

\author{
夏 天 ${ }^{1,2}$, 孟 䙺 ${ }^{1}$, 骆 婷 $^{1}$, 占忠亮 ${ }^{1}$ \\ (1. 中国科学院 上海硅酸盐研究所, 能量转换材料重点实验室, 上海 200050; 2. 中国科学院大学, 北京 100049) \\ 摘 要: 对称固体氧化物燃料电池由于生产过程简单、成本低, 受到了研究者的广泛关注。然而较低的电极催化性 \\ 能制约了其进一步的发展。本研究利用溶胶一凝胶法合成了一系列钻取代 $\mathrm{Sr}_{2} \mathrm{Fe}_{1.5} \mathrm{Mo}_{0.5} \mathrm{O}_{6}$ 的钻钠矿材料 \\ $\left(\mathrm{Sr}_{2-x} \mathrm{Ca}_{x} \mathrm{Fe}_{1.5} \mathrm{Mo}_{0.5} \mathrm{O}_{6-\delta}, x=0,0.2,0.4,0.6\right)$, 并研究了其作为对称固体氧化物燃料电池电极催化剂的性能。X 射线衍射 \\ $(\mathrm{XRD})$ 测试表明所有样品在空气与氢气气氛中均能保持立方钻钛矿结构。而在程序升温还原 (TPR)过程中, $\mathrm{Ca}^{2+}$ 的掺 \\ 入能有效降低还原温度, 提升其对析氧反应的催化活性。对称阳极电池在氢气气氛中的测试表明, 当 $\mathrm{Ca}^{2+}$ 的掺入量 \\ 为 0.6 时电池极化阻抗最小。利用流延骨架与湿化学浸渍法制备了单电池 $\mathrm{SC}_{0.6} \mathrm{FMO}\left|\mathrm{La}_{0.9} \mathrm{Sr}_{0.1} \mathrm{Ga}_{0.8} \mathrm{Mg}_{0.2} \mathrm{O}_{3}(\mathrm{LSGM})\right|$ \\ $\mathrm{SC}_{0.6} \mathrm{FMO}$ 。以氢气作为燃料时, 单电池在 800 与 $650{ }^{\circ} \mathrm{C}$ 的最大功率密度分别为 1.05 与 $0.41 \mathrm{~W} \cdot \mathrm{cm}^{-2}$ 。以上结果表 \\ 明 $\mathrm{Sr}_{2-x} \mathrm{Ca}_{x} \mathrm{Fe}_{1.5} \mathrm{Mo}_{0.5} \mathrm{O}_{6-\delta}$ 可以作为高效对称燃料电池的电极催化剂。
}

关 键 词: 对称固体氧化物燃料电池; 钙针矿结构; 电极材料

中图分类号: TQ174 文献标识码: A 